\title{
Relationship between Anxiety and Interleukin 10 in Female Soccer Players with and Without Premenstrual Syndrome (PMS)
}

\section{Relação dos níveis de ansiedade e da interleucina 10 em jogadoras de futebol de campo com e sem síndrome pré-menstrual (SPM)}

\author{
Roberta Foster ${ }^{1}$ Mauro Vaisberg ${ }^{2}$ Maíta Poli de Araújo ${ }^{1}$ Marcia Aparecida Martins ${ }^{1}$ Tiago Capel ${ }^{1}$ \\ Andre Luis Lacerda Bachi ${ }^{3}$ Zsuzsanna Ilona Katalin de Jármy-Di Bella ${ }^{1}$
}

1 Department of Gynecology, Escola Paulista de Medicina, Universidade Federal de São Paulo - UNIFESP, São Paulo, SP, Brazil

2 Department of Otorhinolaryngology, Escola Paulista de Medicina, Universidade Federal de São Paulo - UNIFESP, São Paulo, SP, Brazil

${ }^{3}$ Department of Physical Activity and Sports Science, Universidade Cruzeiro do Sul - UNICID, São Paulo, SP, Brazil
Address for correspondence Roberta Foster, PhD, Departamento de Ginecologia da Escola Paulista de Medicina da Universidade Federal de São Paulo - UNIFESP, Rua Napoleão de Barros, 608-Vila Clementino, 04024-002 - São Paulo, SP, Brasil (e-mail: robertafoster@ig.com.br).

Rev Bras Ginecol Obstet 2017;39:602-607.

\begin{abstract}
Keywords

- soccer

- menstrual cycle

- premenstrual syndrome

- inflammation

- cytokine

Objective To investigate the level of anxiety and its relationship with interleukin (IL)10 (anti inflammatory cytokine that modulates mood swings) in a group of female soccer players.

Methods Fifty-two eumenorrheic soccer players were evaluated (age $19.8 \pm 4.7$ years). The presence of premenstrual syndrome (PMS) and phases of the menstrual cycle were determined by a daily symptom report (DSR) kept for 3 consecutive months. The concentration of cytokine IL-10 was determined from urine samples collected at four moments: at the follicular and luteal phases of the menstrual cycle, and before (pre) and after (post) the simulated game, and it was quantified by flow cytometry (Luminex xMAP-EMD Millipore, Billerica, MA, USA). The level of anxiety was determined through the $\mathrm{BAI}$ anxiety questionnaire answered by all athletes at the same time of the urine collection. The Student $t$-test, analysis of variance (ANOVA) and Pearson correlation with significance level at $5 \%$ were used for data analysis.

Results We showed that the prevalence of PMS among female soccer players is similar to that reported in the literature. In addition, we showed that the group with PMS has a higher level of anxiety compared with group without PMS $(p=0.002)$. Interleukin-10 analysis in players without PMS revealed that there was a significant decrease in the level of this cytokine before the game during the luteal phase when compared with the follicular phase $(p<0.05)$. The correlation analysis between IL-10 and anxiety showed a negative correlation post-game in the luteal phase in the group without PMS $(p=0.02 ; r=-0.50)$ and a positive correlation post-game in the luteal phase in PMS group $(p=0.04 ; r=0.36)$.
\end{abstract}

received

December 4, 2016

accepted

June 12, 2017

published online

August 28, 2017
DOI https://doi.org/

10.1055/s-0037-1606244. ISSN 0100-7203.
Copyright $\odot 2017$ by Thieme Revinter

Publicações Ltda, Rio de Janeiro, Brazil
License terms

(c) (i) $\ominus$ (\$) 


\section{Resumo}

\author{
Palavras-chave \\ - futebol \\ - ciclo menstrual \\ - síndrome pré- \\ menstrual \\ - inflamação \\ - citocina
}

Conclusion Our results suggest that IL-10 may contribute to reduce anxiety in the group without PMS. This could be attributed to the fact that no IL-10 variation was observed in the group with PMS, which presented higher anxiety symptoms when compared with the group without PMS.

Objetivo Investigar o nível de ansiedade e a sua relação com a interleucina 10 (IL-10) em jogadoras de futebol de campo com e sem síndrome pré-menstrual (SPM). A IL-10 é uma citocina anti-inflamatória que modula o humor e a ansiedade.

Métodos Foram avaliadas 52 jogadoras de futebol de campo eumenorreicas (idade $19.8 \pm 4.7$ anos). A síndrome pré-menstrual (SPM) e as fases do ciclo menstrual foram determinadas pelo questionário de sintomas (DSR) por 3 meses consecutivos. A concentração da interleucina (IL)-10 foi obtida das amostras de urina coletadas em 4 momentos: nas fases folicular e lútea do ciclo menstrual e antes e depois do jogo, e foi quantificada por citometria de fluxo (Luminex xMAP - EMD Millipore, Billerica, MA, USA). O nível de ansiedade foi determinado pelo questionário de ansiedade de BAI, respondido por todas as atletas nos mesmos momentos das coletas de urina. O teste t de Student, a análise de variância (ANOVA) e a correlação de Pearson com nível de significância de $5 \%$ foram utilizados para a análise dos dados.

Resultados Observou-se 59,6\% de SPM nas jogadoras de futebol avaliadas, similar aos dados da literatura. O grupo com SPM possui um estado de ansiedade mais elevado quando comparado ao grupo sem SPM $(p=0,002)$. A IL-10 apresentou diminuição significante na fase lútea antes do jogo em comparação ao mesmo momento na fase folicular nas jogadoras sem SPM $(p<0,05)$. A correlação entre a IL-10 e a ansiedade revelou correlação negativa na fase lútea após o jogo no grupo sem SPM ( $p=0,02$; $r=-0,50$ ), bem como correlação positiva na fase lútea após o jogo no grupo com SPM $(p=0,04 ; r=0,36)$.

Conclusão Os resultados no grupo sem SPM evidenciam provável controle da ansiedade com a contribuição da IL-10. O grupo com SPM; com ansiedade maior que o grupo sem SPM; não teve variação significativa na IL-10, sugerindo dificuldade maior no controle da ansiedade nessas atletas.

\section{Introduction}

The number of female athletes who participate in high performance sports has increased in the last years. ${ }^{1}$ Weight lifting, wrestling, soccer and other sports are examples of modalities in which women have expressive performance. Soccer, in particular, is considered a sport that presents stressful situations and it may generate anxiety responses from the players because it demands motor, technical, tactical and psychological skills. ${ }^{2}$ Thus, it is important to observe the impact of exercise on musculoskeletal and neuroendocrine systems and the influence of the hormonal fluctuations of the menstrual cycle in female athletes during their performances. ${ }^{3}$

There are several studies relating physical activity with menstrual changes, but only a few evaluate the influence of the phases of the menstrual cycle in sports performance, as well as disorders involved in the menstrual cycle, like premenstrual syndrome (PMS). ${ }^{4}$

Premenstrual syndrome is defined as a group of physical and behavioral changes that can affect some women. In general, PMS occurs during the luteal phase of the cycle, after ovulation, until the next menstruation. ${ }^{5-8}$ The prevalence of PMS has a large range and, in Brazil, studies show that 8 to $86 \%$ of women have some kind of symptoms. ${ }^{9}$ The symptoms include breast tenderness, increased breast size, weight gain, legs and whole body swelling, leg pain, increased abdominal size, headache, fatigue, anxiety, irritability, depression and mood swings. ${ }^{10-12}$ The symptoms may manifest with mild to moderate intensity and be repeated for several cycles. ${ }^{10-12}$

Thus, it is critical to emphasize the importance of accurate detection of PMS, making use of complete physical examinations and specific questionnaires for the evaluation of the syndrome. Freeman et $\mathrm{al}^{13}$ created a questionnaire of daily symptoms, the daily symptom report (DSR), for detecting the occurrence of PMS, which is composed of 17 symptoms, with scales ranging from 0 to 5 , according to the severity of each symptom described.

Another important issue in monitoring female athletes refers to psychological aspects and its influence on 
performance. In high performance sports, the psychological assessment seeks the qualification and quantification of the emotional state, occurrence of psychic processes and interpersonal relations during training and competitions, prioritizing teamwork optimization. Indeed, stress caused by strenuous training can lead to a condition of psychophysical inadaptability, triggering negative effects on athletic performance. $^{14}$

Anxiety is a typical "emotional event" of stress; it is directly related to the athlete and can be decisive for his/ her sports performance. ${ }^{15}$ In fact, studies show that women have higher levels of anxiety when compared with men and, and menstrual cycle fluctuations and PMS are aggravating factors. ${ }^{16}$ The Beck Anxiety Inventory (BAI) was created by Beck et $\mathrm{al}^{17}$ and it is composed of a self-report scale to measure aspects of anxiety. It consists of 21 questions that must be answered by the person in reference to him or herself.

The inflammatory mechanism resulting from exercise is well established in the literature; including tissue remodeling and repair. ${ }^{18-21}$ Inflammation plays an essential role when exercise is conducted in a systematic and regular manner. Inflammatory pathways include the action of hormones, neurotransmitters and cytokines, which are responsible for the overall coordination of inflammatory events and their effects associated with exercise. ${ }^{18-21}$

Cytokines are produced and released by cells of the immune system, muscle in activity, adipose tissue and endothelial cells. ${ }^{22}$ Interleukin 10 (IL-10) is a cytokine that plays an anti-inflammatory role in response to exercise, as well as acting in the brain and behavior, improving mood states. $^{22-25}$

In an attempt to understand these aspects, we proposed to evaluate the levels of anxiety and their connection with IL-10 in a female soccer player group, presenting or not PMS, in four moments: before (pre) and after (post) a simulated game and during the two phases of the menstrual cycle: follicular and luteal.

\section{Methods}

This is a longitudinal case-control study. Fifty-two (52) competitive female soccer players (aged: $19.8 \pm 4.7$ years) who had played professionally in championships in the state of São Paulo, Brazil, in 2012 were recruited for the study.

Exclusion criteria included: athletes who were pregnant, exhibited irregular menstrual cycles, fractures, severe ligament injuries, presented genetic or acquired kidney disease; used hormonal contraceptive or antidepressants, anxiolytics, diuretics, steroids or illegal drugs, or did not regularly attend training sessions. All athletes were aware of the potential risks involved in the study and signed the informed written consent form. All experiments were performed in accordance with the Declaration of Helsinki. The Ethics Committee of Universidade Federal de São Paulo approved both the study protocol and consent form (number 1604/10). All athletes performed the same tactical/ technical/ resis- tance training. The soccer specific training was realized five times a week and, after that, the simulated game took place.

The presence of PMS was determined using the DSR questionnaire validated for the Brazilian population by Vieira Filho et al. ${ }^{26}$ All volunteers kindly answered the DSR questionnaire for 3 consecutive months. Menstruation phases (follicular and luteal) were monitored to define urine collection dates more precisely. The follicular phase was estimated to occur from the $1^{\text {st }}$ through the $10^{\text {th }}$ day of the menstrual cycle, and the luteal phase from the $20^{\text {th }}$ day through the beginning of the next period.

Anxiety levels were determined through the BAI anxiety questionnaire validated for the Brazilian population by Cunha. ${ }^{27}$ All athletes answered the questionnaire during both phases of the menstrual cycle and in two periods: before and after the simulated game, totalizing four questionnaires. The guidelines about the questionnaire were explained by a sport psychologist.

Urine samples were collected on four occasions: before and after the simulated game, and during both phases of the menstrual cycle. Sterile containers were used to collect the urine samples and they were subsequently centrifuged at $1,000 \mathrm{rpm}$ for 10 minutes to remove sediment. Urine aliquots were stored at $-80^{\circ} \mathrm{C}$ for cytokine evaluation. Interleukin-10 was evaluated using the HCYTOMAG-60K kit (EMD Millipore, Billerica, MA, USA), according to the manufacturer's instructions, in four moments: before, after the simulated game and during the follicular and luteal phases. A flow cytometer performed with Luminex XMAP Technology (EMD Millipore, Billerica, MA, USA) was used to read and analyze the data. The urine osmolarity was determined with the freezing procedure using a wide range osmometer $3 \mathrm{~W} 2$. All the results obtained from the urine samples were normalized by the values obtained from the urine osmolarity analysis (OSM UR).

Fifty-eight athletes participated in this study. However, considering $80 \%$ of sample power and possible loss of adherence in the study, the final sample was defined with 52 athletes. To check the normality of the data, the Kolmogorov-Smirnov test was used. Data that did not present normal distribution were transformed into square root $(\sqrt{)}$ values. Thus, $t$ test was used to analyze the data that presented a normal distribution. Analysis of variance (ANOVA) was used to evaluate data that did not present normal distribution. For the correlation analysis, we used the Pearson correlation test and the GraphPad Prism software version 4 (GraphPad Software Inc., La Jolla, USA) for the construction of the graphs. All data collected on urine samples were previously modified according to the values obtained from OSM UR by the formula: (gross value / value of OSM UR) x 1,000 . The significance level was set at $5 \%$ $(p<0.05)$.

Data on age, height, weight and BMI were presented as the mean and standard deviation (SD). The Student $t$-test was used to analyze differences in age, height, weight and BMI. Analysis of variance was used for repeated measures and Pearson correlation was used to determine the correlation between IL-10 cytokine and anxiety. 
Table 1 Physical characteristics (the mean \pm standard deviation) of the female soccer players recruited for this study and the most frequent symptoms in the volunteers with PMS (\%)

\begin{tabular}{|c|c|c|c|}
\hline \multirow[t]{2}{*}{ Characteristics } & \multicolumn{3}{|c|}{ Volunteers $(n=52)$} \\
\hline & $\begin{array}{l}\text { with PMS } \\
(N=31)\end{array}$ & $\begin{array}{l}\text { without PMS } \\
(N=21)\end{array}$ & $p$ \\
\hline Age (year) & $18.7 \pm 3.99$ & $20.68 \pm 3.70$ & 0.08 \\
\hline Height (cm) & $165.1 \pm 6.75$ & $165.2 \pm 5.07$ & 0.97 \\
\hline Weight (kg) & $60.8 \pm 7.83$ & $58.51 \pm 6.48$ & 0.28 \\
\hline BMI $\left(\mathrm{Kg} / \mathrm{m}^{2}\right)$ & $22.25 \pm 2.14$ & $21.41 \pm 1.38$ & 0.12 \\
\hline \multicolumn{4}{|l|}{ Symptoms (\%) } \\
\hline Irritability & 80.6 & - & \\
\hline Mood swings & 77.4 & - & \\
\hline Cramps & 67.7 & - & \\
\hline Anxiety & 64.5 & - & \\
\hline $\begin{array}{l}\text { Breast } \\
\text { tenderness }\end{array}$ & 61.3 & - & \\
\hline $\begin{array}{l}\text { Nervous } \\
\text { tension }\end{array}$ & 54.8 & - & \\
\hline
\end{tabular}

Abbreviations: BMI, body mass index; $\mathrm{N}$, number of subjects; $\mathrm{p}, \mathrm{p}$ value; PMS, premenstrual syndrome.

\section{Results}

According to the DRS questionnaire, $59.6 \%$ of the volunteers (31 athletes) presented PMS and 40.4\% (21 athletes) did not present PMS. As shown in -Table 1, no differences were observed in the physical characteristics of the volunteers, presenting or not PMS. Moreover, - Table 1 also depicts the frequency of the main symptoms associated with PMS occurrence observed in the DRS questionnaire.

The analysis of the BAI questionnaire revealed that the group with PMS has a higher level of anxiety when compared with the group without PMS $(p=0.002)$. Analysis of the urine concentration of IL-10 in the volunteers with and without PMS, during the two phases of the menstrual cycle, before (pre) and after (post) a game, revealed a significant decrease of IL-10 levels before the game and during the luteal phase, when compared with pre-game levels during the follicular phase in players without PMS (-Fig. 1-A). There was no significant difference in IL-10 levels in the PMS group in any of the 4 moments evaluated. The correlation analysis between IL-10 and anxiety showed a negative correlation post-game in the luteal phase in the group without PMS (-Fig. 1-B) and a positive correlation post-game in the luteal phase in the PMS group (-Fig. 1-C).

\section{Discussion}

This study is original in the evaluation of female soccer players with and without PMS, correlating anxiety and

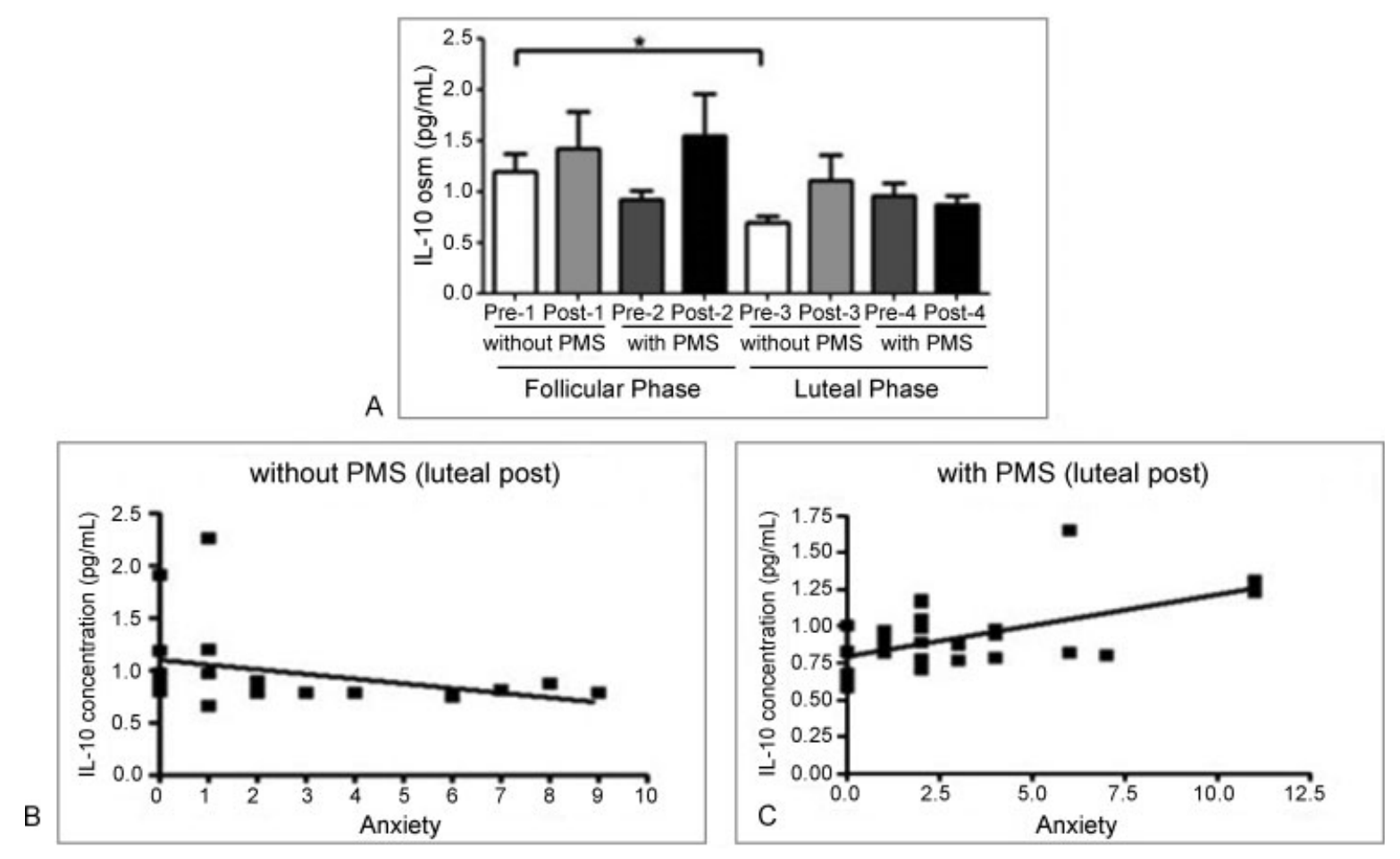

Fig. 1 Analysis of anxiety and urinary concentration of cytokines in female soccer players. (A) concentration of IL-10 in the group without PMS. * denotes differences in the values observed before (pre) the game during the luteal phase and before (pre) the game in the follicular phase $(p<0.05)$. (B) negative correlation in the group without PMS, luteal phase, post-game $(p=0.02, r=-0.50)$. (C) positive correlation in the group with PMS, luteal phase, post-game $(p=0.04, r=0.36)$. Abbreviations: osm, osmolarity; PMS, premenstrual syndrome. 
immune response before and after acute exercise performed in two phases of the menstrual cycle. Factors such as stress and accumulation of daily functions have contributed to the increase of PMS in recent decades. ${ }^{10}$ However, the mechanism of action of multiple factors involved in PMS is still unknown. Estradiol, progesterone, serotonin and gammaaminobutyric acid (GABA) participate in the pathophysiology of women susceptible to PMS. ${ }^{10}$ Indeed, hormonal fluctuations in the luteal phase lead to 5-hydroxytryptamine system (5-HT) alterations in the brain. Five-hydroxytryptamine is a serotonergic neurotransmitter involved in mood swing modulation, anxiety, appetite, sleep and arousal. Gamma-aminobutyric acid is a primary regulator of affection, cognition and the expression of its receptor is regulated by estrogen and progesterone. ${ }^{16}$ Thus, probably due to the interaction between female hormones and these neurotransmitters, it is expected that female soccer players may have PMS, as well as the general female population. ${ }^{28,29}$ Indeed, the result of the prevalence of PMS found in our group (59.6\%) and the most frequent symptoms, including anxiety, is similar to that observed in the Brazilian and international population studies. ${ }^{3,5,9,10,30}$ A study conducted by Teixeira et $\mathrm{al}^{31}$ evaluated the correlation between PMS prevalence and physical activity level (PAL) in a group of healthy women presenting regular menstrual cycle ( 18 to 35 years old). Their most frequent symptoms were anxiety, nervous tension, irritability, crying and insomnia. A negative correlation between the presence of PMS and PAL (lower PAL in women with PMS compared with women without PMS) was observed in the PAL group.

According to Nillni et al ${ }^{16}$ disorders that cause the emergence of anxiety are twice as prevalent in women. Important hormonal fluctuations that occur in the different phases of the menstrual cycle, particularly in the premenstrual - or luteal - phase, may constitute a possible neuromodulatory effect that contributes to the maintenance of anxiety in women.

Our study reveals that the PMS group presents higher levels of anxiety than the group without PMS. Anxiety is very personal and, in the sport context, it arises in a variety of situations, having direct influence on the athlete's performance. For instance, in a situation of "pressure from supporters," the players who are suffering the pressure may present doubtful (debilitating) or challenging (facilitative) feelings. Organic anxiety reactions can cause behavioral and physical changes (athlete's movement and reaction time, for example), leading to altered results in competitions. In fact, there are many variables that influence anxiety levels: type of sport, weather, environment, preparation for competitions, route, etc. In this way, it is very important that the athlete perceives that he/she is suffering from anxiety, the intensity of this feeling and the direction (facilitative or debilitating) in order to channel this sensation positively and to prevent diminished performance. ${ }^{32}$

The balance between pro and anti-inflammatory cytokines in physical exercise-related inflammation is extremely important, since it promotes tissue repair. ${ }^{18}$ Sports performed inadequately can lead to a condition named "sickness behavior." Sickness behavior is known by the increase in cortisol and catecholamine secretion as well as the rise of pro-inflammatory cytokines, such as IL-1 $\beta$ and TNF- $\alpha$, resulting in significant behavioral changes, such as depression, mood swings and anxiety. ${ }^{18}$ On the other hand, the practice of regular and moderate exercise restores the balance of the process just described. ${ }^{33}$ In this study, a decrease in the levels of IL-10 was observed in the group without PMS, pre-game, in the luteal phase, when compared with the follicular phase pre-game. This result indicates the possible action of hormonal fluctuations, which are more exacerbated in the luteal phase, contributing to the reduction of the levels of IL-10. This result is consistent with the study of Lee et $\mathrm{al}^{34}{ }^{34}$ who reported lower IL-10 levels in healthy women during the luteal phase when compared with the follicular phase. In addition, the increase in IL-10 observed in the follicular phase supports previous findings in the literature, in which regular exercise promotes an anti-inflammatory response. ${ }^{35}$ It is important to note that the PMS group showed no significant differences in IL-10 levels in neither phase of the menstrual cycle nor before or after the game.

The correlation between anxiety and IL-10 observed in both groups (with and without PMS), post-game, in the luteal phase, also highlights the knowledge that menstruation is a complex inflammatory process involving intracellular and extracellular signaling events, comprising proinflammatory cytokines, prostaglandins, and immune system cells. ${ }^{36}$ The positive correlation observed in these female soccer players with PMS demonstrate that this group, which presents higher levels of anxiety, produces more IL-10 in an effort, apparently not efficient, to promote the control of this behavioral condition. In addition, the negative correlation found in the PMS-negative group shows that there must be a physiological attempt to control anxiety via IL-10 generation.

A recent study developed by our group ${ }^{25}$ evaluated the relationship among cytokines, hormones and mood swings in marathon runners. The results showed that runners presented elevated levels of IL-10, IL-8 (chemokine associated with tissue repair) and growth hormone $(\mathrm{GH})$ before the race, suggesting that runners probably display mechanisms associated with body preparation for prolonged and strenuous exercise. It is important to note that IL-10, in addition to its anti-inflammatory immune function, also has effects on the brain and behavior, participating in the modulation of mood, anxiety and depression symptoms. ${ }^{26}$

A limitation of our study was the use of urine as a biological sample. We opted for the collection of urine due to the difficulty of collecting blood, since the athletes did not agree to perform the venipuncture. Despite this limitation, the results presented in this study were consistent and relevant.

This study highlights the importance of PMS effect in sports practice and it can be considered as a warning to physicians, coaches and physiologists. However, further research is required to elucidate the mechanism of PMS action on the performance and health of female athletes. 


\section{Conflict of Interests}

Study developed at Escola Paulista de Medicina - Universidade Federal de São Paulo - UNIFESP - São Paulo, SP, Brazil. Authors declare no conflict of interest.

\section{Support}

Financial support provided by Fundação e Amparo à Pesquisa do Estado de São Paulo - FAPESP 10/52424.

\section{References}

1 Monteiro EV, Sartori MGF, Girão MJBC. A tríade da mulher atleta. Femina 2006;34(08):519-521

2 Oliveira SRS, Serassuelo H Junior, Mansano MM, Simões AC. Futebol feminino de competição: uma análise das tendências do comportamento das mulheres/atletas em competir, vencer e estabelecer metas. Rev Bras Educ Fís Esp 2006;20(03):209-218

3 Berenstein E, Klotzel D. Síndrome pré-menstrual. In: Taborda WC, Gomes MTV, editores. Ginecologia: diagnóstico e tratamento, Hospital Israelita Albert Einstein. Rio de Janeiro: Cultura Médica; 2005:69-82

4 David AM, Di Bella ZJ, Berenstein E, Lopes AC, Vaisberg M. Incidência da síndrome pré-menstrual na prática de esportes. Rev Bras Med Esporte 2009;15(05):330-333

5 Zaafrane F, Faleh R, Melki W, Sakouhi M, Gaha L. [An overview of premenstrual syndrome]. J Gynecol Obstet Biol Reprod (Paris) 2007;36(07):642-652

6 Indusekhar R, Usman SB, O'Brien S. Psychological aspects of premenstrual syndrome. Best Pract Res Clin Obstet Gynaecol 2007;21(02):207-220

7 Usman SB, Indusekhar R, O'Brien S. Hormonal management of premenstrual syndrome. Best Pract Res Clin Obstet Gynaecol 2008;22(02):251-260

8 Silva CML, Gigante DP, Minten GC. Premenstrual symptoms and syndrome according to age at menarche in a 1982 birth cohort in southern Brazil. Cad Saude Publica 2008;24(04):835-844

9 Nogueira CWM, Pinto e Silva JL. Prevalence of symptoms in premenstrual syndrome. Rev Bras Ginecol Obstet 2000;22(06): 347-351

10 Federação Brasileira das Associações de Ginecologia e Obstetrícia. Sociedade Brasileira de Medicina de Família e Comunidade. Projeto Diretrizes: tensão pré-menstrual. Rio de Janeiro: AMB/CFM; 2011

11 Approbato MS, Silva CDA, Perini GF, Miranda TG, Fonseca TD, Freitas VC. Premenstrual syndrome and school performance. Rev Bras Ginecol Obstet 2001;23(07):459-462

12 De Mattia AL, Santos CAF, Telles B, Bernauer MC. Síndrome prémenstrual: influências na equipe de enfermagem de centro cirúrgico. Mundo Saúde 2008;32(04):495-505

13 Freeman EW, DeRubeis RJ, Rickels K. Reliability and validity of a daily diary for premenstrual syndrome. Psychiatry Res 1996;65 (02):97-106

14 Freitas DS, Bara Filho M, Miranda R. Marcadores psicológico, fisiológico e bioquímico para determinação dos efeitos da carga de treino e do overtraining. Rev Bras Cineantropom Desempenho Hum 2009;11(04):457-465

15 Spielberger C. Manual do inventário de ansiedade traço-estado. Rio de Janeiro: CEPA; 1979
16 Nillni YI, Toufexis DJ, Rohan KJ. Anxiety sensitivity, the menstrual cycle, and panic disorder: a putative neuroendocrine and psychological interaction. Clin Psychol Rev 2011;31(07):1183-1191

17 Beck AT, Epstein N, Brown G, Steer RA. An Inventory for Measuring Clinical Anxiety: Psychometric Properties. J Consult Clin Psychol 1988;56(06):893-897

18 Silva FOC, Macedo DV. Exercício físico, processo inflamatório e adaptação: uma visão geral. Rev Bras Cineantropom Desempenho Hum 2011;13(04):320-328

19 Nimmo MA, Leggate M, Viana JL, King JA. The effect of physical activity on mediators of inflammation. Diabetes Obes Metab 2013;15(Suppl 3):51-60

20 Petersen AM, Pedersen BK. The anti-inflammatory effect of exercise. J Appl Physiol (1985) 2005;98(04):1154-1162

21 Terra R, Silva SAG, Pinto VS, Dutra PML. Efeito do exercício no sistema imune: resposta, adaptação e sinalização celular. Rev Bras Med Esporte 2012;18(03):208-214

22 Gleeson M. Immune system adaptation in elite athletes. Curr Opin Clin Nutr Metab Care 2006;9(06):659-665

23 Gokhale R, Chandrashekara S, Vasanthakumar KC. Cytokine response to strenuous exercise in athletes and non-athletes-an adaptive response. Cytokine 2007;40(02):123-127

24 Gleeson M. Immune function in sport and exercise. J Appl Physiol (1985) 2007;103(02):693-699

25 Bachi ALL, Rios FJO, Vaisberg PHC, et al. Neuro-immuno-endocrine modulation in marathon runners. Neuroimmunomodulation 2015;22(03):196-202

26 Vieira Filho AHG, Teng CTT, Artes R. Escalas de avaliação de transtorno pré-menstrual. Arch Clin Psychiatry 1998;25(05): 273-278

27 Cunha JA. [Depression and anxiety scales manual in portuguese version]. São Paulo: Casa do Psicólogo; 2001. Portuguese

28 Rodrigues IC, Oliveira E. Prevalência e convivência de mulheres com síndrome pré-menstrual. Arq Ciênc Saúde 2006;13(03): 146-152

29 Yonkers KA, O’Brien PMS, Eriksson E. Premenstrual syndrome. Lancet 2008;371(9619):1200-1210

30 Silva CML, Gigante DP, Carret MLV, Fassa AG. Population Study of Premenstrual Syndrome. Rev Saude Publica 2006;40(01): 47-56

31 Teixeira ALS, Oliveira ECM, Dias MRC. [Relationship between the level of physical activity and premenstrual syndrome incidence]. Rev Bras Ginecol Obstet 2013;35(05):210-214

32 Weinberg RS, Gould D. Fundamentos da psicologia do esporte e do exercício. 2a ed. Porto Alegre. Art Med 2001

33 Moylan S, Eyre HA, Maes M, Baune BT, Jacka FN, Berk M. Exercising the worry away: how inflammation, oxidative and nitrogen stress mediates the beneficial effect of physical activity on anxiety disorder symptoms and behaviours. Neurosci Biobehav Rev 2013;37(04):573-584

34 Lee S, Kim J, Jang B, et al. Fluctuation of peripheral blood T, B, and NK cells during a menstrual cycle of normal healthy women. J Immunol 2010;185(01):756-762

35 Walsh NP, Gleeson M, Shephard RJ, et al. Position statement. Part one: Immune function and exercise. Exerc Immunol Rev 2011; 17:6-63

36 Oertelt-Prigione S. Immunology and the menstrual cycle. Autoimmun Rev 2012;11(6-7):A486-A492 